Technological University Dublin

DÜBLIN

ARROW@TU Dublin

\title{
The application of carbon monoxide in meat packaging needs to be re-evaluated within the EU: An overview
}

Lauren Anne Van Rooyen

Teagasc Food Research Centre

Paul Allen

Teagasc Food Research Centre

David I. O'Connor

Technological University Dublin, david.i.oconnor@tudublin.ie

Follow this and additional works at: https://arrow.tudublin.ie/schfsehart

Part of the Food Science Commons

\section{Recommended Citation}

Van Rooyen LA, Allen P, O'Connor DI. The application of carbon monoxide in meat packaging needs to be re-evaluated within the EU: An overview. Meat Sci. 2017 Oct;132:179-188. doi: 10.1016/

j.meatsci.2017.03.016. Epub 2017 Apr 20. PMID: 28465017.

This Article is brought to you for free and open access by the School of Food Science and Environmental Health at ARROW@TU Dublin. It has been accepted for inclusion in Articles by an authorized administrator of ARROW@TU

Dublin. For more information, please contact arrow.admin@tudublin.ie, aisling.coyne@tudublin.ie, gerard.connolly@tudublin.ie.

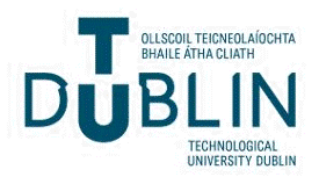


Review

\title{
The application of carbon monoxide in meat packaging needs to be re-evaluated within the EU: An overview
}

\author{
Lauren Anne Van Rooyen ${ }^{\mathrm{a}, \mathrm{b}}$, Paul Allen ${ }^{\mathrm{a}}$, David I. O'Connor ${ }^{\mathrm{b}, *}$ \\ a Teagasc Food Research Centre, Food Quality and Sensory Department, Ashtown, Dublin 15, Ireland \\ b School of Food Science and Environmental Health, Dublin Institute of Technology, Cathal Brugha Street, Dublin 1, Ireland
}

\section{A R T I C L E I N F O}

\section{Keywords:}

Carbon monoxide

Colour enhancer

EU prohibition

Masking spoilage

Consumer acceptance

\begin{abstract}
A B S T R A C T
Carbon monoxide (CO) has many value-added benefits in meat packaging due to its colour stabilising effects and enhancement of meat quality attributes. The regulation of $\mathrm{CO}$ within meat packaging varies worldwide and remains a topical and controversial issue. $\mathrm{CO}$ is prohibited in the EU for use in meat packaging mainly due to fears it may mask spoilage therefore misleading consumers. The issue of consumer acceptance of CO was not considered. This article reviews the most pertinent literature to assess if the problems associated with the prohibition have been addressed. Applying CO pretreatments prior to vacuum packaging enhances colour while allowing discolouration to occur by the use-by-date, thereby addressing concerns about safety. Recent work showing European consumer acceptance of CO in meat packaging demonstrates its future potential within the EU. The information provided may support framing future policies intended to assure consumer protection, safety, choice and interest. Re-evaluation of permitting CO as a packaging gas within the EU may be warranted.
\end{abstract}

\section{Introduction}

Maintaining an attractive colour during retail display remains a challenge to the meat industry. Consumers use "colour" as a reliance quality cue to determine whether a product is safe and fresh to consume (Grebitus, Jensen, \& Roosen, 2013) and colour determines the consumer's perceived quality of meat (Issanchou, 1996). The bright red colour of meat is associated with product freshness and wholesomeness (Kropf, 1980). In recent years, consumers seek more information about the food they consume, whether it is safe to eat, the quality of meat, authenticity, origin and production method or system (Woolfe, 2012). Consumers have a negative attitude towards additives and there has been a growing trend towards healthier and naturally sourced clean label ingredients (Hung, de Kok, \& Verbeke, 2016; Martins, Roriz, Morales, Barros, \& Ferreira, 2016). The meat industry faces the challenge of finding an acceptable clean label ingredient for meat packaging which enhances meat colour. Consumers also have a negative perception of additives even though approved additives have been proven safe for human consumption and many have been derived from natural sources and are not synthetic.

Carbon monoxide (CO) has a history of application within the meat industry as a colour enhancer due to its colour stabilising effects coupled with its antioxidant abilities. The use of $\mathrm{CO}$ as a packaging gas has many benefits including increased colour stability, shelf-life extension due to microbial inhibition properties, enhanced flavour, reduced protein oxidation and lipid oxidation, improved tenderness and prevention of premature browning (El-Badawi, Cain, Samuels, \& Anglemeier, 1964; Gee \& Brown, 1978; Carpenter, Cornforth, \& Whittier, 2001; Jayasingh, Cornforth, Carpenter, \& Whittier, 2001; Krause, Sebranek, Rust, \& Honeyman, 2003; Hunt et al., 2004; Seyfert, Hunt, Mancini, Kropf, \&Stroda, 2004; John et al., 2004, 2005; Mancini, Hunt, Hachmeister, Kropf, \& Johnson, 2005; Cornforth \& Hunt, 2008). The application of low concentrations of CO $(0.4 \%)$ for fresh muscle cuts and ground meat prior to vacuum packaging can maintain product freshness and wholesomeness, assist flexibility during distribution and prevent meat shrinkage (FDA, 2012). However, there is inconsistency worldwide in the regulation of its use within the meat industry and the use of $\mathrm{CO}$ is currently receiving attention among researchers and industry. Differing regulations globally can be a non-tariff barrier to trade limiting the possibilities for exports between countries (Grebitus, Jensen, \& Roosen, 2013).

Globally, the European Food Safety Authority (EFSA), European Commission (EC) and Food and Drug Administration (FDA) are important regulatory authorities. Their responsibilities include adherence to consumer safety and protection, and ensuring quality products which promote human health. EFSA are the foundation of the European safety system and provide scientific advice to the European Commission (EC) prior to policy making. However, the regulations of these

\footnotetext{
* Corresponding author.

E-mail address: David.I.OConnor@dit.ie (D.I. O'Connor).
} 
authorities differ regarding the acceptance of certain additives, more specifically, the acceptance of $\mathrm{CO}$ as a packaging gas.

In the USA, CO was first regulated as a secondary packaging gas in 2002 (FDA, 2002). In 2004, the FDA recognised a concentration of $0.4 \% \mathrm{CO}$ as generally recognised as safe (GRAS) and permitted CO as a primary packaging gas in case-ready packaging systems within the USA (FDA, 2004). However, packages are required to be labelled with "use or freeze by" date of 35 days for intact steaks or roasts and 28 days for mincemeat (FDA, 2004). In addition, packages are required to state "colour is not an accurate indicator of freshness". This is to ensure consumer safety and to avoid misleading consumers about product freshness as $\mathrm{CO}$ can maintain an acceptable colour beyond the spoilage shelf life and consumers generally use colour as a determinant of quality (FDA, 2012). However, since this labelling regulation was enacted, some retailers and some packers in the USA more commonly apply $\mathrm{CO}$ as a secondary packaging gas in a master bag system as labelling is not required in this case. Additionally consumers take very little $\mathrm{CO}$ home with them using this packaging form.

New Zealand and Australia also regulate low concentrations of CO in centralised packaging systems and it is considered a processing aid (Federal Register of Legislative Instruments, 2014). Similarly, Canada also allows the application of $0.4 \% \mathrm{CO}$ as a secondary packaging gas (USDA-FSIS, 2016). Norway applied low concentrations of CO within meat packaging systems for nearly 20 years. However, the regulation of its use ended in 2004 due to the adoption of EU regulations to increase trade with the EU.

In the EU packaging gases are considered as additives and require an "E number" (Walsh \& Kerry, 2002). EU legislation (Directive No 89/ 107/EEC and Directive No 95/2/EC), which applies to additives other than colours and sweeteners and refers specifically to "packaging gases" states that "packaging gases are gases other than air, introduced into a container before, during or after the placing of a foodstuff in that container". Modified atmosphere packaged foods require labelling which states "Packaged in a protective atmosphere" and E numbers should be displayed on the label e.g. E290 for $\mathrm{CO}_{2}$ and E948 for $\mathrm{O}_{2}$ (European Parliament and Council Directive, 1995; Sorheim \& Nissen, 2000). In order for CO to be approved as an additive within the EU the following criteria must be met according to Directive No 89/107/EEC:

- "there can be demonstrated a reasonable technological need and the purpose cannot be achieved by other means which are economically and technologically practicable,

- they present no hazard to the heath of consumer at the level of use proposed, so far as can be judged on the scientific evidence available,

- they do not mislead the consumer."

CO however has not yet been approved as a packaging gas. In 2004, the European Parliament prohibited the use of $\mathrm{CO}$ in meat packaging systems. This may have been due to concerns about $\mathrm{CO}$ masking the microbial spoilage of meat which can mislead consumers about product freshness and be a consumer safety concern (European Commission, 2001). Meat safety is considered by consumers a prerequisite (Van Wezemael, Verbeke, Kügler, de Barcellos, \& Grunert, 2010). Another reason may have been the hazardous potential of the gas which consumers may perceive negatively (Cornforth \& Hunt, 2008). This was contradicted by the European Scientific Committee which stated that low levels of $0.3 \%-0.5 \% \mathrm{CO}$ mixed with carbon dioxide $\left(\mathrm{CO}_{2}\right)$ and nitrogen $\left(\mathrm{N}_{2}\right)$ used as a modified atmosphere gas for meat stored at $4{ }^{\circ} \mathrm{C}$ presented no health threat (European Commission, 2001). Additionally, Sorheim, Aune, and Nesbakken (1997) published a report on the toxicity of $\mathrm{CO}$ which concluded that the application of low concentrations of $\mathrm{CO}$ to meat packaging systems were consumer friendly and no toxic effects were evident. An exposure to a low concentration of $\mathrm{CO}$ ( $50 \mathrm{ppm}$ or less) in the air for $8 \mathrm{~h}$ is considered to be safe (Sebranek \& Houser, 2006).

Several EU countries have made on-going efforts to permit the application of CO within the EU under carefully controlled and regulated conditions; however it may take some time to effect a change (Sorheim et al., 2006). Another important issue with the prohibition is that consumers' preferences were not considered (Grebitus, Jensen, \& Roosen, 2013). A consumer's personal knowledge and media exposure can affect willingness to pay (WTP) (Grebitus, Jensen, Roosen, \& Sebranek, 2013). Concerns of CO being a potentially hazardous gas can negatively influence consumers' acceptance of $\mathrm{CO}$ as a packaging gas as well as concerns for workers' safety. Therefore consumer acceptance of $\mathrm{CO}$ as a packaging technology needs to be considered.

The aim of this article was to review the most recent literature on the benefits and consumer safety issues related to the use of $\mathrm{CO}$ in meat packaging and consumer acceptance of $\mathrm{CO}$ in meat packaging systems. The purpose of this was to assess if the previous issues related to the prohibition of $\mathrm{CO}$ within the EU have been addressed and warrant the re-evaluation of whether $\mathrm{CO}$ should be permitted as a packaging gas within the EU. This information could further assist framing future policies including protection, safety, choice and interest (Grebitus, Jensen, \& Roosen, 2013). If CO was to be permitted as a packaging gas within the EU, the European processors would be able to export $\mathrm{CO}$ pretreated meat to countries where $\mathrm{CO}$ is permitted. Furthermore, application of $\mathrm{CO}$ within the EU could improve profitability and exports for meat producers and retailers as well as meet consumer quality demands as a value added technology (Grebitus, Jensen, Roosen, et al., 2013).

\section{Current meat packaging issues}

Meat packaging innovations can play a pivotal role in meeting the goal of a sustainable future and ensuring food security. It has been estimated that $>20 \%$ of the 263 million tonnes of meat produced globally is lost or wasted, which equates to 75 million bovine raised for no reason (FAO, 2016; Saucier, 2016). The global population is estimated to increase from 7.4 billion to 9.7 billion by 2050 thereby requiring higher meat supplies. Meat consumption is estimated to continue to increase by $17.5 \%$ to 356 million tonnes from 2013 to 2023 (OECD-FAO, 2014). Therefore, with an increasing meat consumption and meat supply required, waste needs to be minimised to contribute to global food security and a sustainable future. A major contributing factor towards meat waste at retail level, mainly in Europe, North America and Industrialised Asia, is consumer discrimination towards discoloured meat products (FAO, 2016) which consumers perceive as unwholesome (Faustman \& Cassens, 1990). However, colour has no effect on taste (Carpenter et al., 2001). In order to reduce food waste and support increased consumer demand and expectation of high quality value-added meat, packaging technology innovations are required. Packaging has a direct influence on the colour and quality of meat (Bernuésa, Olaizolab, \& Corcoranc, 2003). There is a growing demand for more tender meat products. Therefore, packaging technologies which provide both desirable colour and increased tenderness are necessary. However, meat is considered a perishable food due to its biological activity. This can have a negative effect on the colour and is a challenge for the meat industry. Colour is the foremost quality cue judged during consumer purchasing as other quality attributes including tenderness, flavour and juiciness cannot be assessed prior to consumption. Therefore, the meat industry has strived over many decades to prolong the storage life, prevent deterioration and maintain the colour as well as enhancing the eating quality attributes of fresh meat.

At present, the meat industry generally employs a two-stage packaging system where primals are aged in vacuum packs (VP) ("wet aged") before being sliced and transferred to retail VP, vacuum skin packs (VSP) or modified atmosphere packs (MAP). Many of these packaging technologies have been extensively reviewed therefore only the key issues are highlighted in this review. 
High oxygen $\left(\mathrm{O}_{2}\right)$ MAP is a commonly applied second-stage fresh red meat packaging technology. The inclusion of $\mathrm{O}_{2}$, usually at $75-80 \%$, results in the formation of a deep layer of oxymyoglobin, which produces the desirable red colour, while the $\mathrm{CO}_{2}$ is included for its bacteriostatic effect (McMillin, 2008). Unfortunately, extended exposure to $\mathrm{O}_{2}$ can cause lipid and protein oxidation thereby limiting the shelf-life and leading to reduced juiciness, decreased tenderness and the development of off-flavours (Tørngren, 2003; Clausen, 2004; Kim, Huff-Lonergan, Sebranek, \& Lonergan, 2010). During transportation and distribution, the bulky MAP packs are more susceptible to leakages which can contribute to revenue losses (Siegel, 2011).

VP is an anoxic technology and is primarily used within the meat sector for the prolonged storage of fresh primals or subprimals, for distribution to foreign markets by shipment (Egan, Eustace, \& Shay, 1988; Mansur, 1997). VP prevents lipid oxidation, delays microbial spoilage and is the most cost effective, commonly applied method of ageing used to increase tenderness (Eilert, 2005; Obuz, Akkaya, Gök, \& Dikeman, 2014). Consumers consider tenderness as the most essential palatability attribute which determines the overall eating experience (Grobbel, Dikeman, Hunt, \& Milliken, 2008) and can determine consumer repurchases (Hur, Jin, Park, Jung, \& Lyu, 2013). The increased consumer demand for meat tenderness has highlighted the benefits of applying VP within the meat industry. However, the major issue for the success of VP is consumer acceptance of VP meat products which are presented with a dark purple (deoxymyoglobin) appearance, which is perceived as unattractive (Carpenter et al., 2001). Despite a great effort by one of the largest commercial meat companies and retailers in the US, the marketing of individual VP meat cuts was not successful (Lawrence \& Kropf, 2014). College students assisted the marketing in an attempt to educate consumers that VP meat is perfectly acceptable, however while quality was perfectly acceptable, colour did not meet consumer expectations (Lawrence \& Kropf, 2014). However, while this may be the case for US consumers a study carried out by Van Wezemael, Ueland, and Verbeke (2011) reported that European consumers found VP was the most accepted packaging technology (73\%) while MAP was the second most accepted (53\%). Another disadvantage of VP is purge held in the folds of the vacuum package which often leads to increased microbial growth and is less appealing to consumers (Li, Lindahl, Zamaratskaia, \& Lundstrom, 2012).

VSP is a more recent packaging technology that has been designed to prevent package purge loss while maintaining many of the benefits of VP. VSP involves the meat product being placed on a tray which is then covered by an upper and lower layer of packaging film where the upper layer is heated which enables a tight seal over the surface of meat product using vacuum (Lagerstedt, Ahnstrom, \& Lundstrom, 2011; Taylor, Down, \& Shaw, 1990; Vazquez et al., 2004). This consequently prevents package purge, increases product appeal and prevents offodours (Taylor et al., 1990). VSP is increasing in the marketplace in recent years particularly within the EU due to the demand for more tender meat and prolonged shelf-life. Other benefits of VSP include facilitating smaller meat cuts and better portion control which con- tribute to preventing obesity and cater for single-person households, providing convenience and preventing food waste (Bord Bia, 2011). The $\mathrm{O}_{2}$ deficit environment of VSP has similar limitations to that of VP in that the meat has a dark purple colour due to deoxymyoglobin (Lagerstedt, 2011).

A possible solution to overcome the unattractive colour of VP or VSP may be to expose the meat to a gas mixture containing $\mathrm{CO}$ as a pretreatment prior to VP or VSP packaging. This will induce a desirable red colour that will last throughout the display period, coupled with allowing ageing to occur within the package. Thus, the negative quality issues related to high $\mathrm{O}_{2}$ MAP packaging can be avoided. However, there is no literature which states a commercial application of this technique within the meat sector (Robertson, 2010). Furthermore this technology could only be implemented if $\mathrm{CO}$ was permitted within the EU as a packaging gas.

\section{Role of $\mathrm{CO}$ in meat colour}

CO may be described as an odourless, tasteless and colourless gas which is produced by the incomplete combustion of carbon containing materials (Sorheim, Aune, \& Nesbakken, 1997; Zhang, Yu, Xiao, Wang, \& Tian, 2013). CO can readily bind to myoglobin to form carboxymyoglobin, which presents a bright cherry red colour similar to oxymyoglobin (El-Badawi et al., 1964). CO is considered highly stable and myoglobin has a 28-51 times greater affinity for CO than for $\mathrm{O}_{2}$ (De Santos, Rojas, Lockhorn, \& Brewer, 2007). Thus carboxymyoglobin is more resistant to oxidation in comparison to oxymyoglobin and is widely known for its antioxidant properties. Additionally, carboxymyoglobin has a visual spectrum which is similar to that of oxymyoglobin (Gee \& Brown, 1978).

\subsection{Sources of $\mathrm{CO}$}

$\mathrm{CO}$ is naturally synthesised within the human body caused by the breakdown of haemoproteins. A concentration of $1.2-1.5 \%$ carboxyhemoglobin (HbCO) is endogenous in non-smokers, while in smokers it is 3-4\% (European Commission, 2001) (Table 2). The European Commission (2001) reported that inhalation of CO-MAP headspace gas containing $0.3 \%-0.5 \% \mathrm{CO}$ would have no significant effect on the carboxyhaemoglobin ( $\mathrm{HbCO}$ ) in the blood in comparison to other sources of inhalation of $\mathrm{CO}$. The report also stated that the amount of CO present in fresh meat packaged in low concentrations of CO-MAP is similar to that of the endogenous $\mathrm{CO}$. It is also important to note that during cooking a considerable amount $(\sim 85 \%)$ of $\mathrm{CO}$ which is bound to carboxymyoglobin and carboxyhaemoglobin of the packaged meat is lost. Human exposure to $\mathrm{CO}\left(\mathrm{mg} / \mathrm{m}^{3}\right.$ or $\left.\mathrm{ppm}\right)$ and the amount of carboxyhaemoglobin ( $\mathrm{CO} \mathrm{Hb} \%$ ) concentrations in the blood are presented in (Tables $1 \& 2$ ).

Table 1

Human exposure to $\mathrm{CO}$ ( $\mathrm{mg} / \mathrm{m}^{3}$ or $\left.\mathrm{ppm}\right)$.

Extracted from: (Sorheim, Aune, \& Nesbakken, 1997; WHO, 2000; European Commission, 2001; (EEA (European Environment Agency), 2012; EPA, 2017).

\begin{tabular}{|c|c|c|}
\hline Source & Human exposure to $\mathrm{CO}\left(\mathrm{mg} / \mathrm{m}^{3}\right.$ or $\left.\mathrm{ppm}\right)$ & References \\
\hline $\begin{array}{l}\text { Natural background levels (e.g. oxidation of methane in troposphere, decay of } \\
\text { chlorophyll, carbon containing materials) }\end{array}$ & $\begin{array}{l}0.01-0.9 \mathrm{mg} / \mathrm{m}^{3} ; 0.06-0.14 \mathrm{mg} / \mathrm{m}^{3} \\
(0.05-0.12 \mathrm{ppm})\end{array}$ & $\begin{array}{l}\text { (European Commission, 2001; WHO, } \\
\text { 2000) }\end{array}$ \\
\hline $\begin{array}{l}\text { Petrol-fuelled or faulty propane-fuelled ice resurfacer used at ice- hockey games } \\
\text { from an average of } 7 \text { arenas (average ice-hockey game period 1.5-2 h) }\end{array}$ & $40-46 \mathrm{mg} / \mathrm{m}^{3}(35-40 \mathrm{ppm})$ & $(\mathrm{WHO}, 2000)$ \\
\hline Large European cities ( $8 \mathrm{~h}$ exposure) & $<20 \mathrm{mg} / \mathrm{m}^{3}(17 \mathrm{ppm})$ & (WHO, 2000) \\
\hline $\begin{array}{l}\text { Environmental tobacco smoke in dwellings, offices, vehicles and restaurants ( } 8 \mathrm{~h} \\
\text { exposure) }\end{array}$ & $23-46 \mathrm{mg} / \mathrm{m}^{3}(17 \mathrm{ppm})$ & (WHO, 2000) \\
\hline Homes with gas appliances & $60-115 \mathrm{mg} / \mathrm{m}^{3}(53-100 \mathrm{ppm})$ & $(\mathrm{WHO}, 2000)$ \\
\hline Maximum recommended exposure & $\begin{array}{l}9 \mathrm{ppm} \text { of } \mathrm{CO}(8 \mathrm{~h} \text { exposure); } 35 \mathrm{ppm}(1 \mathrm{~h} \\
\text { exposure); } 10 \mathrm{mg} / \mathrm{m}^{3} \text { ( } 8 \mathrm{~h} \text { daily mean) }\end{array}$ & $\begin{array}{l}\text { EEA (European Environment Agency), } \\
\text { 2012; EPA, 2017) }\end{array}$ \\
\hline
\end{tabular}


Table 2

Carboxyhaemoglobin (CO Hb \%) concentrations in the blood.

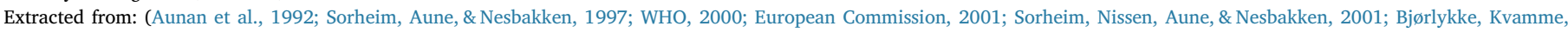
Slinde, \& Sørheim, 2012).

\begin{tabular}{|c|c|c|}
\hline Source & $\begin{array}{l}\text { Concentration in human blood (CO } \\
\mathrm{Hb} \%)\end{array}$ & References \\
\hline $\begin{array}{l}\text { Production of } \mathrm{CO} \text { exogenous in the human body due to the } \\
\text { breakdown of haemoproteins }\end{array}$ & $0.5 \% ; 04-0.7 \%$ & $\begin{array}{l}\text { (European Commission, 2001; Sorheim, Aune, \& Nesbakken, 1997; WHO, } \\
\text { 2000; Bjørlykke et al., 2012) }\end{array}$ \\
\hline Pregnant woman & $0.7-2.5 \%$ & $($ WHO, 2000) \\
\hline Foetuses of non-smoker mothers & $0.4-2.6 \%$ & (WHO, 2000) \\
\hline $\begin{array}{l}\text { Hypermetabolism patients caused by haemolytic } \\
\text { anaemia \& certain drugs }\end{array}$ & $4-6 \%$ & (WHO, 2000) \\
\hline $\begin{array}{l}\text { Non-smokers (exogenous combined with environmental factors } \\
\text { e.g. pollutants) }\end{array}$ & $1.2-1.5 \%$ & $\begin{array}{l}\text { (European Commission, 2001; Sorheim, Aune, \& Nesbakken, 1997; } \\
\text { Sorheim et al., 2001) }\end{array}$ \\
\hline Smokers/cigarette smoke & $3-4 \%$ & $\begin{array}{l}\text { (Aunan et al., 1992; European Commission, 2001; Sorheim, } \\
\text { Aune, \& Nesbakken., 1997; Sorheim et al., 2001) }\end{array}$ \\
\hline Healthy adults with no adverse health effects & $<5 \%$ & (Sorheim, Aune, \& Nesbakken, 1997) \\
\hline Vulnerable individuals should not exceed & $\sim 2 \%$ & (Sorheim, Aune, \& Nesbakken, 1997; European Commission, 2001) \\
\hline
\end{tabular}

\section{Historical perspective of the use $\mathrm{CO}$}

CO has a long history of applications within the food industry, including, meat, fish, vegetable and fruit processing (Cornforth \& Hunt, 2008). Over a century ago, a patent was approved for the application of $\mathrm{CO}_{2} / \mathrm{CO}$ gaseous mixtures to extend the shelf-life of meat (Church, 1994). El-Badawi et al. (1964) was one of the first studies to report that colour stability in fresh beef could be increased to a period of 15 days with the addition of $2 \%$ CO to air. Similarly, Clark, Lentz, and Roth (1976) reported that a lower concentration of $1 \%$ CO mixed with $99 \%$ $\mathrm{N}_{2}$ had similar effects with increased colour stability and prolonged odour shelf-life in beef samples. Further benefits of $\mathrm{CO}$ were demonstrated by Gee and Brown (1978), who reported that atmospheres of $1 \%$ $\mathrm{CO}, 50 \% \mathrm{CO}_{2}$ and $49 \%$ air increased the microbial shelf-life and colour stability by 4.5 days in minced meat stored at $2{ }^{\circ} \mathrm{C}$ (Gee \& Brown, 1978). From 1985 to 2004, the Norwegian meat sector used CO concentrations of $0.3-0.5 \%$ in MAP and case-ready packaging systems of beef, pork and lamb (Sorheim, Erlandsen, Nissen, Lea, \& Hoyem, 1997; Sorheim, Nissen, \& Nesbakken, 1999). During this period $60 \%$ of all retail meat marketed in Norway was packaged using low concentrations of CO (Sorheim, 2006). Additionally, the USA have applied CO within vegetable processing since the 1970's to prolong the shelf-life of iceberg lettuce during distribution (Mermelstein, 1977; Kader, 1983) and it is currently applied in centralised meat packaging systems in the USA.

\section{Benefits of $\mathrm{CO}$ in meat packaging}

Many researchers have reported numerous benefits of applying CO to meat packaging systems under refrigerated storage conditions, including increased colour stability, prolonged shelf-life due to microbial inhibition, decreased protein oxidation, enhanced flavour, improved tenderness in anaerobic packaging systems, absence of bone darkening and prevention of premature browning (El-Badawi et al., 1964; Gee \& Brown, 1978; Carpenter et al., 2001; Jayasingh et al., 2001; Krause et al., 2003; Seyfert et al., 2004; Hunt et al., 2004; John et al., 2004, 2005; Mancini et al., 2005; Cornforth \& Hunt, 2008). Krause et al. (2003) reported that CO-MAP with mixtures of $0.5 \%$ CO, $70 \%$ and $29.5 \% \mathrm{~N}_{2}$ significantly enhanced the colour and sensory attributes of pork chops in comparison to overwrap, VP and MAP. Additionally, lipid oxidation was reduced when compared to overwrap packaging. While numerous studies have reported the effects of $\mathrm{CO}$ on extended colour stability, additional benefits of the application of $\mathrm{CO}$ have also been reported. Woodruff and Silliker (1985), reported a concentration of $10 \% \mathrm{CO}$ can penetrate $0.63-0.94 \mathrm{~cm}$ beneath the surface of meat, forming a bright stable red carboxymyoglobin layer while inhibiting microbial growth, further preventing odour and slime by-products. Additionally, Clark et al. (1976) showed increasing CO concentrations with the balance gas being $\mathrm{N}_{2}$ on beef rump steaks inhibited the growth of psychotropic bacteria which also had a positive effect on increased odour shelf-life. This result was due to CO having the ability to increase the lag phase and reduce the log phase. CO has also been reported to prevent the growth of bacteria, yeasts and moulds (Mansur, 1997). Pathogenic bacteria such as Escherichia coli O157 (E. coli O157) were reported to be inhibited in ground beef samples enclosed in CO-MAP gas mixtures of $0.4 \% \mathrm{CO}, 60 \% \mathrm{CO}_{2}, 39.6 \% \mathrm{~N}_{2}$ (Nissen, Alvseike, Bredholt, Holck, \& Nesbakken, 2000). Brooks et al. (2008) concluded similar results with CO-MAP systems with a $0.4 \%$ CO concentration where pathogenic salmonella and E. coli 0157 were reduced in comparison to packaging systems without CO. Other pathogens reported to be inhibited by low concentration of $\mathrm{CO}$ and high $\mathrm{CO}_{2}$ include Listeria monocytogenes and Yersinia enterocolitica (European Commission, 2001). CO has also been reported to inhibit food spoilage bacteria including Brochothrix thermosphacta, pseudomonads, Pseudomonas fluorescens and Achromobacter (Gee \& Brown, 1978; Sorheim et al., 1999).

Furthermore, John et al. (2005) reported that beef steaks packaged in $0.4 \%$ CO-MAP or in VP can prevent premature browning and reduce oxidation and rancidity. Ultra low $\mathrm{O}_{2}$ atmospheres with a concentration of $0.4 \% \mathrm{CO}$ have also resulted in increased tenderness when compared to high- $\mathrm{O}_{2}$ MAP (Grobbel et al., 2008). Additionally, Liu et al. (2014) reported that $0.4 \%$ CO-MAP packaging systems can maintain higher metmyoglobin reducing activity (MRA), which is linked to increased colour stability, compared to high- $\mathrm{O}_{2}$ MAP.

\section{Application of $\mathrm{CO}$ pretreatment in fresh meat}

A possible response to the consumer resistance to the purple colour of VP beef is the application of $\mathrm{CO}$ as a pretreatment prior to packaging. Applying CO pretreatments prior to VP has previously been reported by numerous researchers (Clark et al., 1976; Lentz, 1979; Rozbeh, Kalchayanand, Field, Johnson, \& Ray, 1993; Brewer et al., 1994; Jayasingh et al., 2001; Sagarnaga, 2006; Aspé, Roeckel, Martí, \& Jiménez, 2008; O'Connor \& Allen, 2011; Sakowska, Guzek, Glabska, \& Wierzbicka, 2016; Sakowska, Guzek, Sun, \& Wierzbicka, 2016; Sakowska, Guzek, \& Wierzbicka, 2016; Van Rooyen, Allen, Crawley, \& O'Connor, 2017; Van Rooyen, Allen, Gallgaher, \& O'Connor, 2016) (Table 3). Brewer et al. (1994) reported that exposing beef to CO prior to VP can maintain the red colour in the VP. Krause et al. (2003), suggested that the pretreatment of fresh meat prior to VP would promote the desirable cherry red pigment for 21 days during centralised packaging and distribution, due to the stability of the carboxymyoglobin layer which maintains the red appearance in the absence of CO-MAP. A report by Humphreys (1996) stated that approximately $97 \%$ of beef in the USA 


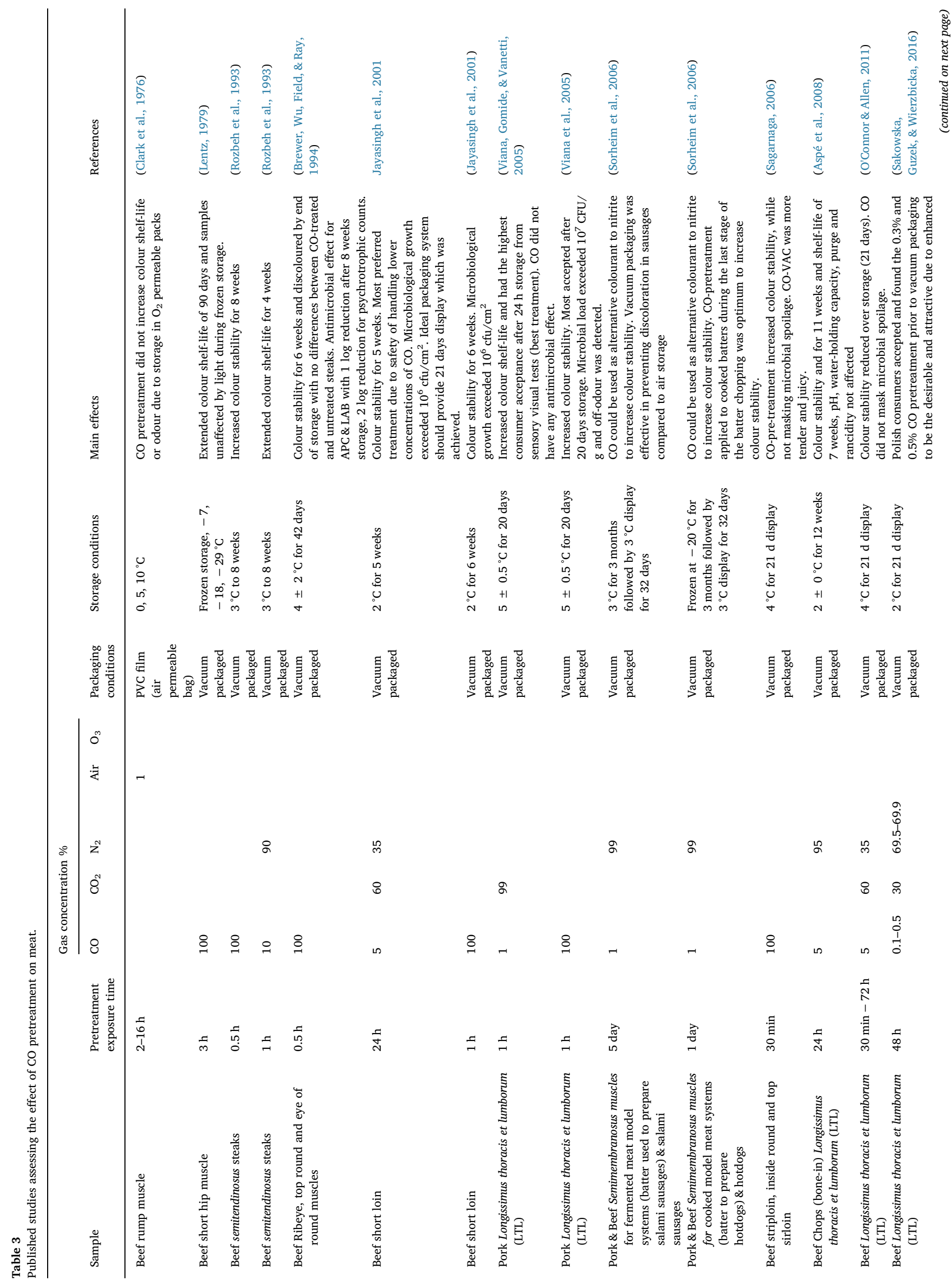




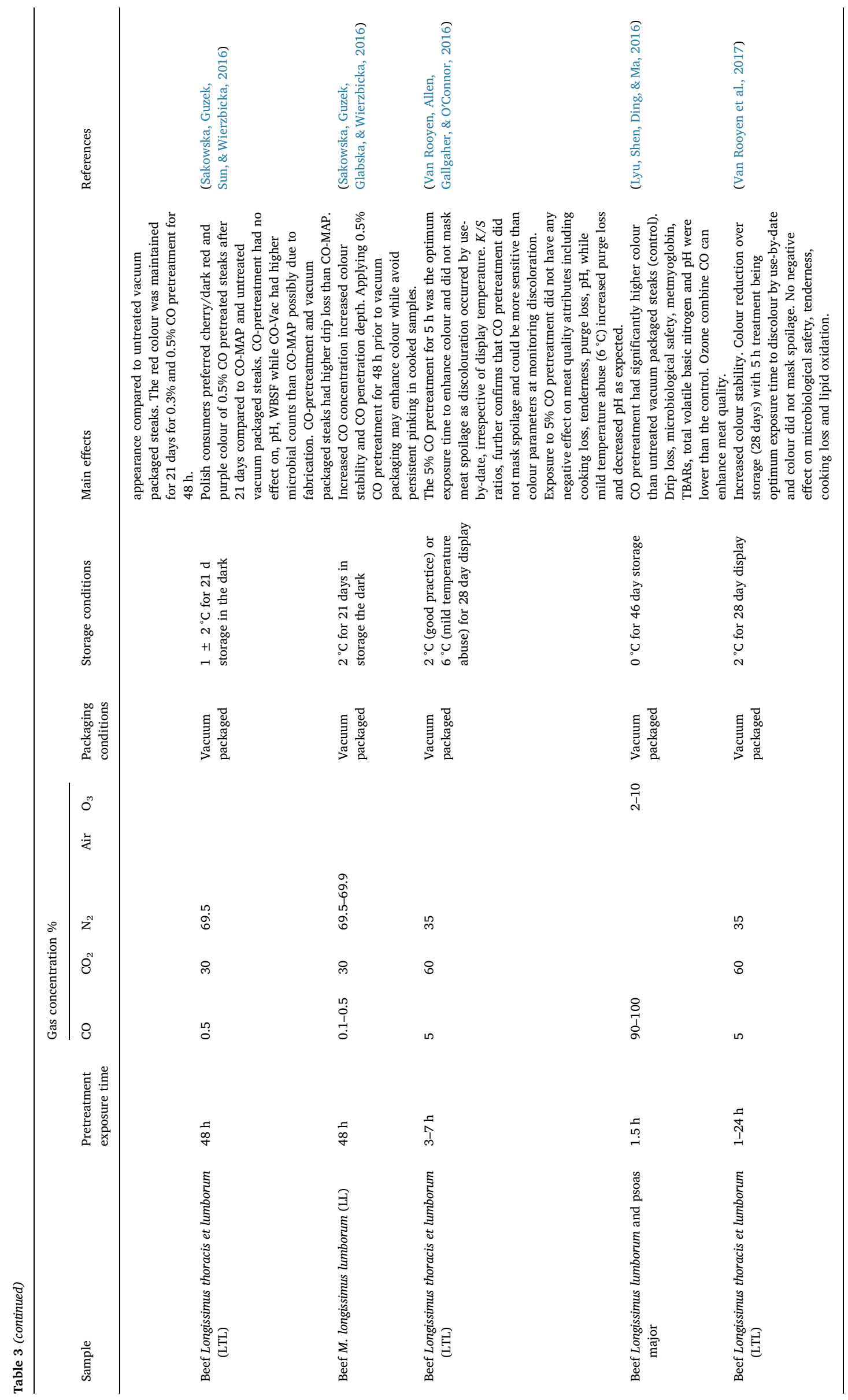


meat market experiences fabrication or VP at some stage during processing or distribution. Therefore implementing $\mathrm{CO}$ pretreatments prior to packaging would not be unfamiliar.

CO pretreatments have long since been employed. Clark et al. (1976) reported improved colour stability and decreased odour for beef rump muscles stored in 0.5-10\% CO-MAP atmospheres at 0,5 and $10{ }^{\circ} \mathrm{C}$. However, in the same study pre-treatments of $99 \%$ CO and $1 \%$ air followed by air storage gave no further colour or odour decrease. Later work did show a positive effect from exposing beef samples to $100 \%$ CO for $3 \mathrm{~h}$ before VP as colour shelf-life was increased (Lentz, 1979). Furthermore, Rozbeh et al. (1993) pretreated beef semitendinosus steaks with gas mixtures of $10 \% \mathrm{CO}+90 \% \mathrm{~N}_{2}$ for $60 \mathrm{~min}$ and $100 \% \mathrm{CO}$ for $30 \mathrm{~min}$ at $3{ }^{\circ} \mathrm{C}$ before VP. A stable red colour was maintained during 4 weeks storage for muscles pre-treated with $10 \% \mathrm{CO}$, while beef treated with $100 \%$ CO obtained a colour shelf-life of 8 weeks (Rozbeh et al., 1993). A study carried out by Brewer et al. (1994) reported colour stability effects and microbial inhibition for beef steaks due to the $100 \%$ CO pretreatment for $30 \mathrm{~min}$ prior to vacuum packaging at refrigerated temperatures. A study carried out by Brewer et al. (1994) reported colour stability effects and microbial inhibition for beef ribeye and round steaks due to the $100 \%$ CO pretreatment for 30 min prior to vacuum packaging at refrigerated temperatures. $\mathrm{CO}$ pretreatment significantly enhanced redness up to 6 weeks compared to the untreated control. Additionally, an extended shelf-life for CO pretreated steaks due to microbial inhibition was observed as after 8 weeks of storage there was a $1 \log$ reduction for aerobic plate counts and lactic acid bacteria (LAB) counts in comparison to an untreated control and a $2 \log$ reduction for psychotropic bacteria counts. Similarly, Jayasingh et al. (2001) investigated the colour stability of beef steaks exposed to pretreatments of $100 \% \mathrm{CO}$ for $1 \mathrm{~h}$ and $5 \% \mathrm{CO}$ for $24 \mathrm{~h}$, prior to vacuum packaging. The 5\% CO pretreatments prolonged the colour shelf-life for 5 weeks whereas the $100 \%$ CO pretreatment maintained a colour shelflife of 6 weeks. The objective of the experiment was to achieve a colour stability of 21 days (maturation (7 days), retail display (7 days) and consumer use by date (7 days)) with the lowest $\mathrm{CO}$ concentration. This was achieved using a concentration of $5 \% \mathrm{CO}$. CO pre-treatments before vacuum packaging for retail would greatly assist distribution within the meat industry. Aspé et al. (2008) analysed the effect of CO pretreatment and film properties on the quality of VP beef chops. They applied a pretreatment of $5 \% \mathrm{CO}$ with $95 \% \mathrm{~N}_{2}$ to beef chops for $24 \mathrm{~h}$ at $2{ }^{\circ} \mathrm{C}$ before VP in thermo-contractile packs or non-heat-contractile packs. The microbial shelf-life was extended to 11 weeks in both types of VP, however heat-contractile packs reduced purge loss and improved colour stability compared to non-heat contractile packages. Furthermore $\mathrm{pH}$, water holding capacity, purge loss, and rancidity were not influenced by CO pretreatment. A study carried out by Sagarnaga (2006) compared three different packaging technologies; MAP $\left(80 \% \mathrm{O}_{2} / 20 \% \mathrm{CO}_{2}\right)$, $\mathrm{CO} /$ VAC $100 \%$ CO pretreatment for 30 min prior to VP and CO/MAP $100 \%$ $\mathrm{CO}$ pretreatment for $30 \mathrm{~min}$ before packaging in MAP $\left(30 \% \mathrm{CO}_{2} / 70 \%\right.$ $\mathrm{N}_{2}$ ). The study showed that CO/VAC increased colour stability and extended shelf-life without masking microbial spoilage and improved overall acceptability compared to CO/MAP and MAP (Sagarnaga, 2006). Additionally, CO-VAC was more tender and juicy than other treatments. The benefits of $\mathrm{CO}$ pretreatments prior to VP compared to CO-MAP include a more compact pack size thereby reducing storage and lowering costs during transportation thus increasing profitability for industry (Sakowska, Guzek, Sun, et al., 2016).

Although CO has many advantages, concerns have been raised in the past that CO may mask the microbial spoilage of meat (Kropf, 1980). The high stability of carboxymyoglobin can lead consumers to falsely perceive the freshness of meat as colour is used as an indicator of freshness. Eilert (2005) disagreed and reported that CO does not mask spoilage and can reduce flavour oxidation and odour. Sorheim (2006) reported that varying the meat exposure period to $\mathrm{CO}$ during pretreatment could be used to regulate the colour stability during display without masking microbial spoilage. A preliminary study carried out by
O'Connor and Allen (2011) applied pretreatment regimes to beef Longissimus thoracis et lumborum (LTL) steaks to find a regime that would allow the formation of metmyoglobin to occur by the use-by date. The study was designed to combine the advantages of VP with the cherry-red colour of steaks in CO-MAP packaging while ensuring that discolouration occurred by the end of the shelf life to address consumers concerns about spoilage being masked. The study included variations in the exposure times of $5 \%$ CO from $30 \mathrm{~min}$ to $72 \mathrm{~h}$. An initial bright cherry red colour reduced over a storage period of 21 days. Following this, Van Rooyen et al. (2017) determined the optimum exposure time with a $5 \% \mathrm{CO}$ concentration to be $5 \mathrm{~h}$ as this allowed discoloration to occur by the end of a 28-day display period $\left(2{ }^{\circ} \mathrm{C}\right)$. The $5 \%$ CO pre-treatment for $5 \mathrm{~h}$ had no negative effect on microbiological safety, cooking loss, tenderness and lipid oxidation at the end of storage. Therefore these results address the previous issues associated with the ban of $\mathrm{CO}$ as microbial spoilage was not masked if the correct combination of exposure time and $\mathrm{CO}$ concentration is applied. The $\mathrm{CO}$ exposure time was greatly reduced compared to previous studies which applied a 5\% CO pretreatment for $24 \mathrm{~h}$ (Jayasingh et al., 2001; Aspé et al., 2008), thus potentially improving efficiency and reducing process time.

The European Commission (2001) also raised a valid concern that if CO meat products are stored under inappropriate conditions, for example increased temperature which can occur during mishandling or transportation; the presence of CO may mask visual evidence of spoilage. Therefore, Hunt et al. (2004) reported that 0.4\% CO-MAP did not mask meat spoilage in ground beef, loineye, inside round and tenderloin after storage under inappropriate storage conditions of mild temperature abuse $\left(6^{\circ} \mathrm{C}\right)$ as microbial spoilage was not accelerated. Van Rooyen et al. (2016), found that mild temperature abuse $\left(6^{\circ} \mathrm{C}\right)$ did not alter the conclusion that a $5 \%$ CO pretreatment for $5 \mathrm{~h}$ did not mask spoilage as discolouration occurred by use-by-date, irrespective of display temperature. The only effect of the higher temperature on quality attributes was an increased purge loss and decreased $\mathrm{pH}$.

Another important issue to address if $\mathrm{CO}$ is to be approved within the $\mathrm{EU}$ is persistent pinking (carboxymyoglobin layer being retained after cooking), which has been an on-going problem in the US especially for meat which has been exposed to CO-MAP. However, the application of $\mathrm{CO}$ pretreatments prior to vacuum packaging may overcome this issue as $\mathrm{CO}$ is not present in the pack during storage. The very short exposure time to $\mathrm{CO}$ may reduce or eliminate the formation of persistent pinking after cooking. Recently, Sakowska, Guzek, Glabska, and Wierzbicka (2016) reported that reducing the CO-MAP concentration to $0.1 \%$ or using a $0.5 \%$ CO pretreatment exposure time of $48 \mathrm{~h}$ prior to vacuum packaging can prevent the persistent pinking in cooked beef striploin steaks. However, it is important to note that carboxymyoglobin formation is proportional to gas concentration and exposure time.

Also, further research is needed on various muscle types as each muscle type has specific physiological properties which influence colour stability and post-mortem biochemical changes (Seyfert, Mancini, Hunt, Tang, \& Faustman, 2007). Therefore on-going, research by this group (unpublished results) is investigating the CO pretreatment of steaks from different muscles.

\section{Consumer perception and acceptance of $\mathrm{CO}$}

Consumers' attitudes, perception, responses and acceptance regarding novel packaging technologies can also vary globally (Grebitus, Jensen, \& Roosen, 2013). The prohibition of the application of CO in MAP within the EU did not consider consumer preferences when the ban was put in place as the Commission presumed consumers' purchase intent of CO meat packaging systems would not be of interest (Grebitus, Jensen, Roosen, \& Sebranek, 2013). Sensitivity to information, personal knowledge and media exposure of CO may negatively influence consumer acceptance of $\mathrm{CO}$ meat packaging (Grebitus, 
Jensen, \& Roosen, 2013; Grebitus, Jensen, Roosen, \& Sebranek, 2013). Therefore a choice study was carried out by Grebitus, Jensen, and Roosen (2013) on ground beef which evaluated German and US consumer acceptance and WTP of packaging technologies such as MAP and CO-MAP which included labelling on the packages, informing the consumers of improved meat quality attributes due to the packaging technology type. US consumers preferred prolonged shelf-life and clear information about the packaging technology. However, WTP for COMAP decreased for US consumers when labelling information was included about the role of $\mathrm{CO}$ as a colour stabiliser but did not affect WTP of German consumers. Overall, the results indicated that German consumers would prefer to have an option of food packaging technologies applied with modified atmosphere gases such as $\mathrm{CO}$ as consumers were attracted to the enhanced meat colour. Additionally, German consumers were willing to pay $€ 3.75$ more for a desirable cherry red appearance in ground beef while US consumers would only pay an additional $€ 0.69$. However, consumers in both countries had increased preference towards enhanced cherry red colour. This result agrees with work carried out by Carpenter et al. (2001) and Killinger, Calkins, Umberger, Feuz, and Eskridge (2004) who both concluded that consumers have a preference for the bright cherry red colour.

Similarly two recent consumer studies were carried out on Polish consumers (Sakowska, Guzek, Sun, \& Wierzbicka, 2016; Sakowska, Guzek, \& Wierzbicka, 2016) to evaluate whether Polish consumers would accept $\mathrm{CO}$ in meat packaging systems. The first study by Sakowska, Guzek, and Wierzbicka (2016) evaluated consumer preferences towards CO pretreatments $(0.1 \%, 0.3 \%$ and $0.5 \%)$ of beef striploin steaks exposed for $48 \mathrm{~h}$ prior to VP compared to untreated vacuum packaged steaks. Consumers had a preference and increased desire to purchase steaks packaged after $0.3 \%$ and $0.5 \%$ CO pretreatments as they had the most attractive cherry red colour. Consumers did not accept untreated vacuum packaged beef steaks as they were considered the least attractive and desirable. Following this, these authors carried out another study (Sakowska, Guzek, Sun, \& Wierzbicka, 2016) whereby Polish consumer acceptance and preference of CO-MAP $(0.5 \%)$ was compared to $\mathrm{CO}$ pretreatments $(0.5 \%)$ prior to VP. In agreement with the previous study (Sakowska, Guzek, and Wierzbicka, 2016), Polish consumers preferred and had the highest likelihood to purchase for CO pretreatments (0.5\%) in comparison to CO-MAP.

Therefore, the results from these studies in two European countries (Germany and Poland) show promise for the future potential application of $\mathrm{CO}$ within the $\mathrm{EU}$, despite the current EU prohibition of MAP with CO. Consumer acceptance and WTP of CO in meat packaging within the EU can provide beneficial information to assist future marketing and product positioning in the market and increase profitability for meat producers and retailers due to enhanced value-added and meat quality attributes. Moreover this information can assist in the development of future policy making which focuses on the protection of consumer choice and interest (Grebitus, Jensen, \& Roosen, 2013).

\section{Conclusion}

$\mathrm{CO}$ as a pretreatment applied prior to VP or VSP may play an important role in assisting packaging innovations to overcome some of the challenges the meat industry faces. It demonstrates future potential as a value added meat packaging technology in terms of maintaining an acceptable colour, providing prolonged storage, meeting consumer demand for increased tenderness as well as preventing negative issues associated with other packaging technologies. The colour stabilising abilities of CO may reduce global food waste due to meat discoloration. As a result this may further assist the goal of a sustainable future, ensuring food security and increase profitability for the meat industry. Allowing the ageing process to take place within the VP or VSP pack as opposed to carcass or primal ageing will decrease energy usage, storage facilities and distribution costs.
This article has reviewed some of the most recent studies of CO in meat packaging systems in order to address the issues associated with the prohibition within the EU. The criteria that must be met for $\mathrm{CO}$ to be permitted as an additive within the EU.

(Directive No 89/107/EEC) have been satisfactorily addressed therefore a reconsideration by the EU Commission is justified. $\mathrm{CO}$ is widely reported as a colour enhancer for a perishable food product such as meat, therefore providing a technological need. $\mathrm{CO}$ has presented no health threat at the level of use proposed as a primary packaging gas in MAP $(0.3 \%-0.5 \%)$ for meat stored at $4{ }^{\circ} \mathrm{C}$ according to the European Scientific Committee (European Commission, 2001). Additionally low concentrations of $\mathrm{CO}$ to meat packaging systems have been reported to be consumer friendly and have no toxic effects (Sorheim, Aune, et al., 1997; Sorheim \& Nissen, 2000). CO has previously been reported to mask meat spoilage and this was the primary concern raised for the prohibition as this may mislead consumers. However, Van Rooyen et al. (2017) demonstrated that the application of the 5\% CO pretreatment for $5 \mathrm{~h}$ prior to vacuum packaging achieves enhanced colour, while allowing discoloration to occur by the end of a 28-day display period $\left(2{ }^{\circ} \mathrm{C}\right)$, so as to not mask spoilage. This ensures consumers have a reliable visual indication of freshness and addresses previous concerns about consumer safety as consumers are not misled by an attractive colour being retained beyond the microbiological spoilage life. However, it is important to note that the correct combination of $\mathrm{CO}$ gas concentration and exposure time needs to be determined for the desired use-by date and possibly be varied for different cuts. Recent European consumer acceptance studies from Germany and Poland, demonstrate promising future potential of the application of $\mathrm{CO}$ within the EU.

This review could provide useful information to guide the framing of future policies intended to support consumer protection, safety, choice and interest (Grebitus, Jensen, \& Roosen, 2013). Additionally, this article may educate consumers of the benefits of $\mathrm{CO}$ and resolve any misconception or negative media influence of $\mathrm{CO}$ as a packaging gas so that consumers may make an informed choice. In addition, if CO was permitted as a packaging gas within the EU European processors would be able to export $\mathrm{CO}$ pretreated meat to countries where $\mathrm{CO}$ is permitted, potentially increasing exports and profits. The information provided here may be used to make a case for the re-evaluation of $\mathrm{CO}$ as a permitted packaging gas within the EU.

\section{Acknowledgements}

Lauren-Anne van Rooyen is in receipt of a Teagasc Walsh Fellowship. The authors would like to acknowledge the Department of Agriculture, Food and Marine (DAFM) for their financial support through the Food Institutional Research Measure (FIRM) (Project 11/F/ 060). The authors would also like to gratefully acknowledge Professor Melvin Hunt, Kansas State University, Manhattan, USA for his valuable help and insightful knowledge during the initial stages of this article.

\section{References}

Aspé, E., Roeckel, M., Martí, M. C., \& Jiménez, R. (2008). Effect of pre-treatment with carbon monoxide and film properties on the quality of vacuum packaging of beef chops. Packaging Technology and Science, 21(7), 395-404.

Aunan, K., Låg, M., Schwarze, P., Nygaard, P., Braathen, O. A., \& Aune, T. (1992). Carbon monoxide. Effects of ambient air pollution on health and environment-air quality guidelines (pp. 154-170). Oslo, Norway: State Pollution Control Authority (SFT) (in Norwegian).

Bernuésa, A., Olaizolab, A., \& Corcoranc, K. (2003). Labelling information demanded by European consumers and relationships with purchasing motives, quality and safety of meat. Meat Science, 65, 1095-1106.

Bjørlykke, G. A., Kvamme, B. J., Slinde, E., \& Sørheim, O. (2012). Use of carbon monoxide in slaughtering processing and packaging of muscle foods. In J. C. Taylor (Ed.), Advances in chemistry research (vol. 14). Nova Science Publishers, Inc.

Bord Bia (2011). Meat trends - a report on meat trends in retail foods service. Retrieved from http://www.bordbia.ie/industry/manufacturers/insight/publications/ bbreports/Documents/Meat\%20Trends-\%20A\%20Report\%20on\%20Meat $\% 20$ Trends $\% 20$ in $\% 20$ Retail $\% 20$ and $\% 20$ Foodservice $\% 20-\% 20$ August $\% 202011$.pdf.

Brewer, S. M., Wu, S., Field, R. A., \& Ray, B. (1994). Carbon monoxide effects on color and 
microbial counts of vacuum-packaged fresh beef steaks in refrigerated storage. Journal of Food Quality, 17(3), 231-244.

Brooks, J. C., Alvarado, M., Stephens, T. P., Kellermeier, J. D., Tittor, A. W., Miller, M. F., \& Brashears, M. M. (2008). Spoilage and safety characteristics of ground beef packaged in traditional and modified atmosphere packages. Journal of Food Protection, 71(2), 293-301.

Carpenter, C. E., Cornforth, D. P., \& Whittier, D. (2001). Consumer preferences for beef color and packaging did not affect eating satisfaction. Meat Science, 57(4), 359-363.

Church, N. (1994). Developments in MAP and related technologies. Trends in Food Science and Technology, 5, 345 .

Clark, D. S., Lentz, C. P., \& Roth, L. A. (1976). Use of carbon monoxide for extending shelf-life of prepackaged fresh beef. Canadian Institute of Food Science and Technology Journal, 9, 114-117.

Clausen, I. (2004, August 8-13). Sensory evaluation of beef loin steaks stored in different atmospheres. Paper presented at the Proceedings 50th International Congress of Meat Science and Technology Helsinki, Finland.

Cornforth, D., \& Hunt, M. (2008). Low-oxygen packaging of fresh meat with carbon monoxide. American meat association white paper series (pp. 1-10).

De Santos, F., Rojas, M., Lockhorn, G., \& Brewer, M. S. (2007). Effect of carbon monoxide in modified atmosphere packaging, storage time and endpoint cooking temperature on the internal color of enhanced pork. Meat Science, 77(4), 520-528.

Directive No 89/107/EEC (1988). On the approximimation of the laws of the Member States concerning food additives authorized for use in foodstuffs intended for human consumption.

Directive No 95/2/EC (1995). Of the European Parlament and of the Council on Food additives other than colours and sweetners.

EEA (European Environment Agency) (2012). Air quality in Europe. European Environment Agency technical report No 4/2012. 84.

Egan, A. F., Eustace, I. J., \& Shay, B. J. (1988, August 29-September 2). Meat packagingMaintaining the quality and prolonging the storage life of chilled beef, pork and lamb. Paper presented at the Proceedings of Industry Day: Part of the 34th International Congress of Meat Science and Technology, Brisbane, Australia.

Eilert, S. J. (2005). New packaging technologies for the 21st century. Meat Science, 71(1), 122-127.

El-Badawi, A. A., Cain, R. F., Samuels, C. E., \& Anglemeier, A. F. (1964). Color and pigment stability of packaged refrigerated beef. Food Technology, 753, 159-163.

EPA (2017). National ambient air quality standards (NAAQS). Retrieved from https:// www.epa.gov/co-pollution.

European Commission (2001). Opinion of the Scientific Committee on Food on the use of carbon monoxide as component of packaging gases in modified atmosphere packaging.

FAO (2016). SAVE FOOD: Global initiative on food loss and waste reduction.

Faustman, C., \& Cassens, R. G. (1990). The biochemical basis for discoloration in fresh meat: A review. Journal of Muscle Foods, 217-243.

FDA (2002). Letter from Rulis, AM to Greenberg, E, GRAS Notice No. GRN 000083 C.F.R.

FDA (2004). Letter from Tarantino, L. to Kushner, G.J. FDA (Re: GRAS Notice No. GRN 000143).

FDA (2012). Agency response letter GRAS notice no. GRN 000251. U.S. Food \& Drug.

Federal Register of Legislative Instruments (2014). In F. R. o. L. Instruments (Ed.), Australia New Zealand food standards code - Standard 1.3.3 - processing aids (pp. 1-25). F2014C00795 (vol. standard 1.3.3. Agency.

Gee, D. L., \& Brown, W. D. (1978). Extension of shelf-life in refrigerated ground beef stored under an atmosphere containing carbon dioxide and carbon monoxide. Journal of Agriculture Food Chemistry, 26, 274-276.

Grebitus, C., Jensen, H. H., \& Roosen, J. (2013). US and German consumer preferences for ground beef packaged under a modified atmosphere - Different regulations, different behaviour? Food Policy, 40, 109-118.

Grebitus, C., Jensen, H. H., Roosen, J., \& Sebranek, J. G. (2013). Fresh meat packaging: Consumer acceptance of modified atmosphere packaging including carbon monoxide. Journal of Food Protection, 76(1), 99-107.

Grobbel, J. P., Dikeman, M. E., Hunt, M. C., \& Milliken, G. A. (2008). Effects of packaging atmospheres on beef instrumental tenderness, fresh color stability, and internal cooked color. Journal of Animal Science, 86(5), 1191-1199.

Humphreys, P. (1996). Vacuum packaging of fresh meat. In S. A. Taylor, A. Raimundo, M. S, \& F. J. M. Smulders (Eds.), An overview. In meat quality and meat packaging (pp. 285-). Utrecht: ECCEAMST.

Hung, Y., de Kok, T. M., \& Verbeke, W. (2016). Consumer attitude and purchase intention towards processed meat products with natural compounds and a reduced level of nitrite. Meat Science, 121, 119-126.

Hunt, M. C., Mancini, R. A., Hachmeister, K. A., Kropf, D. H., Merriman, M., DelDuca, G., \& Milliken, G. (2004). Carbon monoxide in modified atmosphere packaging affects color, shelf life, and microorganisms of beef steaks and ground beef. Journal of Food Science, 69(1), C45-C52.

Hur, S. J., Jin, S. K., Park, J. H., Jung, S. W., \& Lyu, H. J. (2013). Effect of modified packaging and vacuum packaging on quality characteristics of low grade beef during cold storage. Journal of Animal Science, 26, 1781-1789.

Issanchou, S. (1996). Consumer expectations and perceptions of meat and meat product quality. Meat Science, 43(Supplement 1), 5-19.

Jayasingh, P., Cornforth, D. P., Carpenter, C. E., \& Whittier, D. (2001). Evaluation of carbon monoxide treatment in modified atmosphere packaging or vacuum packaging to increase color stability of fresh beef. Meat Science, 59(3), 317-324.

John, L., Cornforth, D., Carpenter, C. E., Sorheim, O., Pettee, B. C., \& Whittier, D. R. (2004). Comparison of color and thiobarbituric acid values of cooked hamburger patties after storage of fresh beef chubs in modified atmospheres. Journal of Food Science, 69(8), C608-C614.

John, L., Cornforth, D., Carpenter, C. E., Sorheim, O., Pettee, B. C., \& Whittier, D. R. (2005). Color and thiobarbituric acid values of cooked top sirloin steaks packaged in modified atmospheres of $80 \%$ oxygen, or $0.4 \%$ carbon monoxide, or vacuum. Meat Science, 69(3), 441-449.

Kader, A. A. (1983). Physiological and biochemical effects of carbon monoxide added to controlled atmospheres opn fruits. Acta Horticulturae, 138, 221-225.

Killinger, K. M., Calkins, C. R., Umberger, W. J., Feuz, D. M., \& Eskridge, K. M. (2004). Consumer visual preference and value for beef steaks differing in marbling level and color. Journal of Animal Science, 82(11), 3288-3293.

Kim, Y. H., Huff-Lonergan, E., Sebranek, J. G., \& Lonergan, S. M. (2010). High-oxygen modified atmosphere packaging system induces lipid and myoglobin oxidation and protein polymerization. Meat Science, 85(4), 759-767.

Krause, T. R., Sebranek, J. G., Rust, R. E., \& Honeyman, M. S. (2003). Use of carbon monoxide packaging for improving the shelf life of pork. Journal of Food Science, 68(8), 2596-2603.

Kropf, D. H. (1980, June 22-25). Effects of retail display conditions on meat color. Paper presented at the 33rd Reciprocal Meat Conference Proceedings, West Lafayette, Indiana.

Lagerstedt, A. (2011). Packaging methods and storage time: Effects of beef quality. Swedish University of Agricultural Sciences.

Lagerstedt, A., Ahnstrom, M. L., \& Lundstrom, K. (2011). Vacuum skin pack of beef - a consumer friendly alternative. Meat Science, 88(3), 391-396.

Lawrence, T. E., \& Kropf, D. H. (2014). Vacuum. In M. Dikeman, \& C. Devine (Vol. Eds.), Encyclopedia of meat sciences second edition. Vol. 3, (pp. 26-33). San Diego, USA Academic Press.

Lentz, C. P. (1979). Effect of light intensity and other factors on the color of frozen prepackaged beef. Canadian Institute of Food Science and Technology Journal, 12, 47-50.

Li, X., Lindahl, G., Zamaratskaia, G., \& Lundstrom, K. (2012). Influence of vacuum skin packaging on color stability of beef longissimus lumborum compared with vacuum and high-oxygen modified atmosphere packaging. Meat Science, 92(4), 604-609.

Liu, C., Zhang, Y., Yang, X., Liang, R., Mao, Y., Hou, X., \& Luo, X. (2014). Potential mechanisms of carbon monoxide and high oxygen packaging in maintaining color stability of different bovine muscles. Meat Science, 97(2), 189-196.

Lyu, F., Shen, K., Ding, Y., \& Ma, X. (2016). Effect of pretreatment with carbon monoxide and ozone on the quality of vacuum packaged beef meats. Meat Science, 117, 137-146.

Mancini, R. A., Hunt, M. C., Hachmeister, K. A., Kropf, D. H., \& Johnson, D. E. (2005). Exclusion of oxygen from modified atmosphere packages limits beef rib and lumbar vertebrae marrow discoloration during display and storage. Meat Science, 69(3), 493-500.

Mansur, R. T. (1997). Modified atmosphere packaging. In A. L. Brody, \& K. S. Marsh (Eds.), The Wiley encyclopedia of packaging technology(2nd ed.). New York, Chichester, Weinheim, Brisbane, Singapore, Toronto: John Wiley \& Sons, Inc.

Martins, N., Roriz, C. L., Morales, P., Barros, L., \& Ferreira, I. C. F. R. (2016). Food colorants: Challenges, opportunities and current desires of agro-industries to ensure consumer expectations and regulatory practices. Trends in Food Science \& Technology, $52,1-15$.

McMillin, K. W. (2008). Where is MAP going? A review and future potential of modified atmosphere packaging for meat. Meat Science, 80(1), 43-65.

Mermelstein, N. H. (1977). Sucess or failure? How the food technology industrial achievement award winners have fared over the years. Food Technology, 31(7), 36-58.

Nissen, H., Alvseike, O., Bredholt, S., Holck, A., \& Nesbakken, T. (2000). Comparison between the growth of Yersinia enterocolitica, Listeria monocytogenes, Escherichia coli O157: H7 and Salmonella spp. in ground beef packed by three commercially used packaging techniques. International Journal of Food Microbiology, 59(3), 211-220.

O'Connor, D. I., \& Allen, P. (2011, August 7-12). The use of carbon monoxide as a prepackaging treatment in Beef. Paper presented at the 57th International Congress of Meat Science and Technology. Ghent-Belgium.

Obuz, E., Akkaya, L., Gök, V., \& Dikeman, M. E. (2014). Effects of blade tenderization, aging method and aging time on meat quality characteristics of Longissimus lumborum steaks from cull Holstein cows. Meat Science, 96(3), 1227-1232.

OECD-FAO. OECD-FAO agricultural outlook 2014-2023. (2014). Retrieved from http:// stats.oecd.org/index.aspx?queryid $=58654$ (Accessed 09/09/2016) .

Robertson, G. L. (2010). Food packaging and shelf life: A practical guide. Boca Raton: CRC.

Rozbeh, M., Kalchayanand, N., Field, R. A., Johnson, M. C., \& Ray, B. (1993). The influence of biopreservatives on the bacterial level of refrigerated vacuum packaged beef. Journal of Food Safety, 13, 99-111.

Sagarnaga, L. M. R. (2006). Does pressurized pre-treatment with carbon monoxide (CO) improve fresh beef shelf-life characteristics in case-ready packaging systems? Oklahoma State University.

Sakowska, A., Guzek, D., Glabska, D., \& Wierzbicka, A. (2016). Carbon monoxide concentration and exposure time effects on the depth of CO penetration and surface color of raw and cooked beef longissimus lumborum steaks. Meat Science, 121, $182-188$.

Sakowska, A., Guzek, D., Sun, D. W., \& Wierzbicka, A. (2016). Effects of 0.5\% carbon monoxide in modified atmosphere packagings on selected quality attributes of $M$. longissimus dorsi beef steaks. Journal of Food Process Engineering, 1-10.

Sakowska, A., Guzek, D., \& Wierzbicka, A. (2016). Effects of carbon monoxide treatment before vacuum packaging on the physical parameters and consumer evaluations of raw beef. Food Science and Technology, 36(3), 485-492.

Saucier, L. (2016). Microbial spoilage, quality and safety within the context of meat sustainability. Meat Science, 120, 78-84.

Sebranek, J., \& Houser, T. (2006). Use of CO for red meats: Current research and recent regulatory approvals. In W. S. Otwell (Ed.), Modified atmospheric processing and packaging of fish. Iowa: Blackwell Publishing.

Seyfert, M., Hunt, M. C., Mancini, R. A., Kropf, D. H., \& Stroda, S. L. (2004). Internal premature browning in cooked steaks from enhanced beef round muscles packaged in 
high-oxygen and ultra-low oxygen modified atmospheres. Journal of Food Science, 69(2), 142-146.

Seyfert, M., Mancini, R. A., Hunt, M. C., Tang, J., \& Faustman, C. (2007). Influence of carbon monoxide in package atmospheres containing oxygen on colour, reducing activity, and oxygen consumption of five bovine muscles. Meat Science, 75(3), $432-442$.

Siegel, D. (2011, June 22). An update on packaging fresh meat with nitrite containing film. Paper presented at the 64th Reciprocal Meat Conference Kansas State University.

Sorheim, O. (2006). Prospects for utilization of carbon monoxide in the muscle food industry. In S. Otwell, H. Kristinsson, \& M. Balaban (Eds.), Modified atmospheric processing and packaging of fish. Iowa: Blackwell Publishing.

Sorheim, O., Aune, T., \& Nesbakken, T. (1997). Technological, hygienic and toxicological aspects of carbon monoxide used in modified-atmosphere packaging of meat. Trends in Food Science \& Technology, 8(9), 307-312.

Sorheim, O., Erlandsen, T., Nissen, H., Lea, P., \& Hoyem, T. (1997). Effects of modified atmosphere storage on colour and microbiological shelf life of normal and pale, soft and exudative pork. Meat Science, 47(1-2), 147-155.

Sorheim, O., Langsrud, O., Cornforth, D. P., Johannessen, T. C., Slinde, E., Berg, P., \& Nesbakken, T. (2006). Carbon monoxide as a colorant in cooked or fermented sausages. Journal of Food Science, 71(9), 549-555.

Sorheim, O., \& Nissen, H. (2000). Current technology for MAP meat. 39. Food Marketing and Technology.

Sorheim, O., Nissen, H., Aune, T., \& Nesbakken, T. (2001, July 24-28). Use of carbon monoxide in retail meat packaging. Paper presented at the 54th Annual Reciprocal Meat Conference. Indianapolis, Indiana.

Sorheim, O., Nissen, H., \& Nesbakken, T. (1999). The storage life of beef and pork packaged in an atmosphere with low carbon monoxide and high carbon dioxide. Meat Science, 52, 157-164.

Taylor, A. A., Down, N. F., \& Shaw, B. G. (1990). A comparison of modified atmosphere and vacuum skin packing for the storage of red meats. International Journal of Food Science and Technology, 25(1), 98-109.

Tørngren, M. A. (2003, August 31st-September 5th). Effect of packing method on colour and eating quality of beef loin steaks. Paper presented at the Proceedings 49th International Congress of Meat Science and Technology. Campinas, Brazil.

USDA-FSIS (Producer). (2016, Jan 29). Export Requirements for Canada. Retrieved from http://www.fsis.usda.gov/wps/portal/fsis/topics/international-affairs/exportingproducts/export-library-requirements-by-country/Canada.

Van Rooyen, L. A., Allen, P., Crawley, S. M., \& O'Connor, D. I. (2017). The effect of carbon monoxide pretreatment exposure time on the colour stability and quality attributes of vacuum packaged beef steaks. Meat Science, 129, 74-80.

Van Rooyen, L. A., Allen, P., Gallgaher, E. I., \& O'Connor, D. I. (2016, August 14th-19th). CO pretreatments of vacuum packaged beef steaks. Paper presented at the $62 \mathrm{nd}$ International Congress of Meat Science \& Technology. Bangkok Thailand.

Van Rooyen, L. A., Allen, P., \& O'Connor, D. I. (2016, August 21st-25th). The effect of pretreatment regimes to enhance meat quality on vacuum packaged beef steaks. Paper presented at the 18th World Congress of Food Science and Technology. Dublin, Ireland.

Van Wezemael, L., Ueland, O., \& Verbeke, W. (2011). European consumer response to packaging technologies for improved beef safety. Meat Science, 89(1), 45-51.

Van Wezemael, L., Verbeke, W., Kügler, J. O., de Barcellos, M. D., \& Grunert, K. G. (2010) European consumers and beef safety: Perceptions, expectations and uncertainty reduction strategies. Food Control, 21(6), 835-844.

Vazquez, B. I., Carreira, L., Franco, C., Fente, C., Cepeda, A., \& Barros-Velaazquez, J. (2004). Shelf life extension of beef retail cuts subjected to an advanced vacuum skin packaging system. European Food Research and Technology, 218(2), 118-122.

Viana, E. S., Gomide, L. A. M., \& Vanetti, M. C. D. (2005). Effect of modified atmospheres on microbiological, color and sensory properties of refrigerated pork. Meat Science, 71(4), 696-705.

Walsh, H. M., \& Kerry, J. P. (2002). Meat packaging. In J. Kerry, J. Kerry, \& D. Ledward (Eds.), Meat processing. Cambridge: Woolhead Publishing Limited.

WHO (2000). Carbon monoxide Air Quality Guidelines(2nd ed.). (Copenhagen, Denmark).

Woodruff, R. E., \& Silliker, J. H. (1985). Process and composition for producing and maintaining good color in fresh meat, fresh poultry and fresh fish. U.S. Pat, 4, $522-835$.

Woolfe, M. (2012). 22 - Labelling of meat, poultry, seafood and their products in the EU A2. In J. P. Kerry (Ed.), Advances in meat, poultry and seafood packaging (pp. 596-630). Woodhead Publishing.

Zhang, S., Yu, Y., Xiao, C., Wang, X., \& Tian, Y. (2013). Effect of carbon monoxide on browning of fresh-cut lotus root slice in relation to phenolic metabolism. LWT - Food Science and Technology, 53(2), 555-559. 